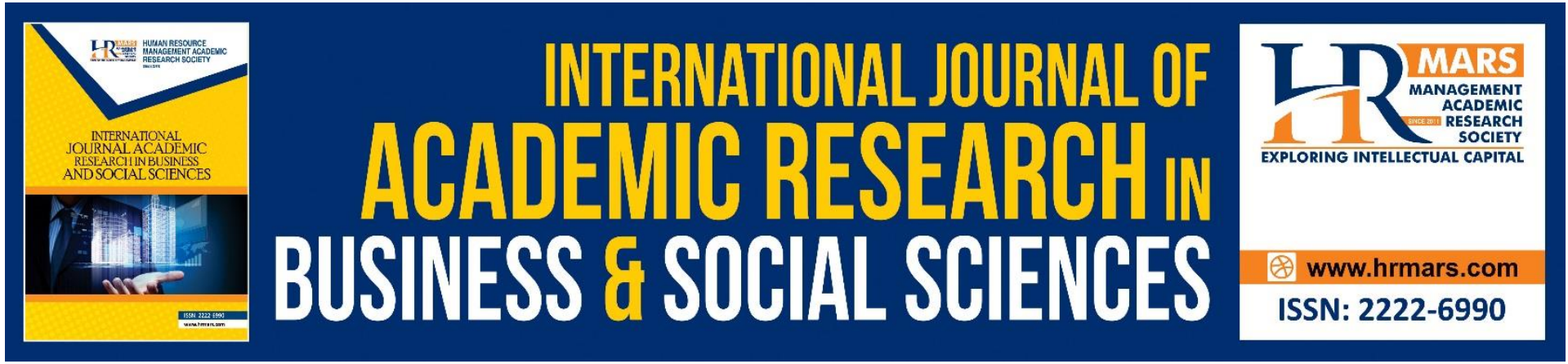

\title{
Climate Change-Friendly Behavior: A Review of Preservice Teachers
}

Siti Aishah Othman \& Siti Nur Diyana Mahmud

To Link this Article: http://dx.doi.org/10.6007/IJARBSS/v11-i8/10701

DOI:10.6007/IJARBSS/v11-i8/10701

Received: 10 June 2021, Revised: 12 June 2021, Accepted: 06 August 2021

Published Online: 30 August 2021

In-Text Citation: (Othman \& Mahmud, 2021)

To Cite this Article: Othman, S. A., \& Mahmud, S. N. D. (2021). Climate Change-Friendly Behavior: A Review of Preservice Teachers. International Journal of Academic Research in Business and Social Sciences, 11(8), 1584-1595.

Copyright: (c) 2021 The Author(s)

Published by Human Resource Management Academic Research Society (www.hrmars.com)

This article is published under the Creative Commons Attribution (CC BY 4.0) license. Anyone may reproduce, distribute, translate and create derivative works of this article (for both commercial and non-commercial purposes), subject to full attribution to the original publication and authors. The full terms of this license may be seen at: http://creativecommons.org/licences/by/4.0/legalcode

Vol. 11, No. 8, 2021, Pg. 1584 - 1595

http://hrmars.com/index.php/pages/detail/IJARBSS

JOURNAL HOMEPAGE

Full Terms \& Conditions of access and use can be found at http://hrmars.com/index.php/pages/detail/publication-ethics 


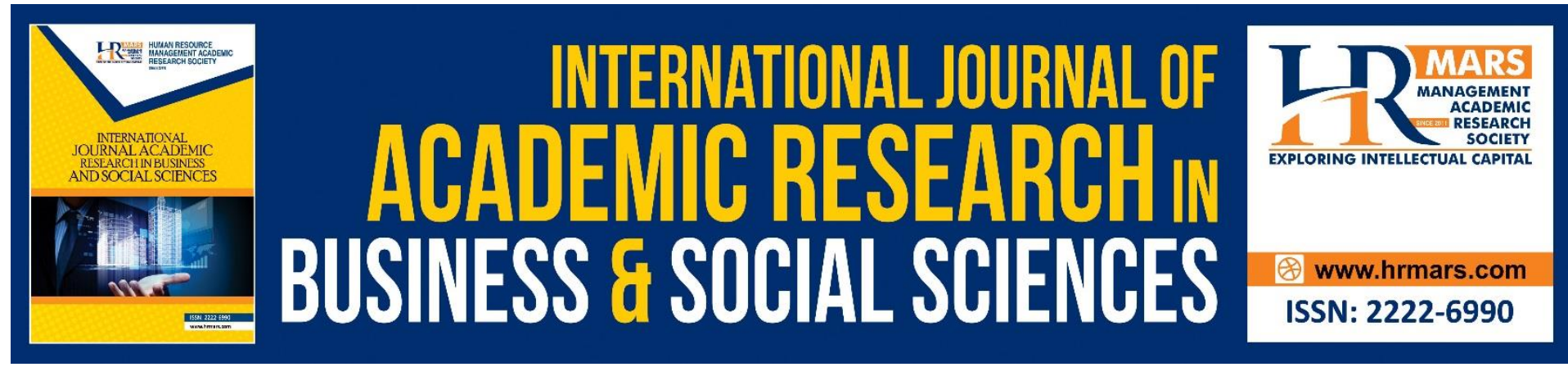

\title{
Climate Change-Friendly Behavior: A Review of Preservice Teachers
}

\author{
Siti Aishah Othman \& Siti Nur Diyana Mahmud \\ Faculty of Education, Universiti Kebangsaan Malaysia
}

\begin{abstract}
To date, climate change is a major issue debated globally. Climate change has impacted human life and the environment. Mitigating the effects of climate change requires individuals with friendly behaviour towards climate change. This study aimed to examine the relationship of preservice teachers' friendly behaviour towards climate change through the level of knowledge, awareness, risk perception, and attitude of preservice teachers. This study involved 256 preservice teachers at four universities in the state of Selangor. A questionnaire with a five-point Likert scale was used for the purpose of data collection. The data obtained were analysed using SPSS 23.0 software. The results of the study indicated that there was a significant but moderate relationship between awareness and risk perception with the climate change-friendly behaviour of preservice teachers. The study also found that there was a significantly weak relationship between knowledge and attitudes towards preservice teachers' climate change-friendly behaviours. Preservice teachers have the knowledge and awareness of climate change that has a negative impact on socio-economy and disrupts the ecosystem of the human life. However, this awareness does not influence the preservice teachers to demonstrate attitudes and behaviours towards reducing the effects of climate change.
\end{abstract}

Keywords: Climate Change Awareness, Climate Change Knowledge, Risk Perception, Climate Change Attitude, Climate Change Friendly Behaviour, Preservice Teachers

\section{Introduction}

Nowadays, climate change is one of the major ecological problems (Hashim, 2015). The misconception in society about "climate change" is that global warming is the climate change (Nerem et al., 2018). Poortinga et al (2019) study on global awareness of environmental issues found that developing countries have lower levels of awareness compared to developed countries, although these countries were directly influenced by climate change. This is also supported by Saad et al (2018) study which found that Malaysia is no exception as the people have a low level of awareness of climate change. A study conducted in 2007 by the World Wildlife Fund-Malaysia Organization and partner found that $45 \%$ of adults and students in Malaysia are keen to learn the causes of environmental problems (Ahmad et al., 2012).

Although the level of awareness of Malaysian citizens is moderate especially about climate change, environmental research, especially on climate change in Malaysia, is given less attention. The issue of climate change is considered not alarming by the Malaysian 
community because they have not been able to see the effects of climate change. This is also due to the lack of information about the effects of climate change on sociocultural factors unlike the air pollution issues such as haze that can be seen and the effects can be felt.

In Malaysia, there are many researches that have been conducted on climate change in various aspects but less research has been carried out to determine the actual attitude of environmentally friendly behaviour among preservice teachers in Malaysia. Masud et al. (2013) have proposed a unique model to determine environmentally friendly behaviour among the public in Malaysia. Behaviour is often associated with the attitudes displayed by a person. According to Madawan et al (2016), attitudes can be seen in a person's behaviour and Zakariah (2016) noted that behaviour in practice is related to the attitude manifested by a person. Behaviour also refers to a person's actions in changing things towards positive action. Friendly behaviour to climate change in this study refers to the behaviour and actions of preservice teachers to reduce the impact of climate change locally and globally.

\section{Climate Change Awareness}

Studies on climate change have been widely conducted in Malaysia through various perspectives but the number of studies on climate change awareness among students and preservice teachers is scarce. Previous studies involved the in-service teachers and preservice science teachers, but studies on climate change issues among teachers of other subjects are limited. Besides, there are many studies on environmentally friendly behaviour but not on climate change issues. Most research in Malaysia focused on perception and public awareness instead of preservice teachers. Previous studies on climate change involving preservice teachers from abroad have been used as reference for this study. However, studies on environmental issues and climate change in Malaysia involving students, in-service teachers, and the public are also benchmarked for the level of awareness, knowledge, risk perception, attitudes, and climate change-friendly behaviours of preservice teachers in Malaysia.

Iman Syaiffudin and Md. Hashim (2019) found that there is a relationship between the levels of awareness among the population to control the problem of climate change. However, the relationship is quite weak and this study also discovered that the level of unsatisfactory awareness among the residents of Telok Panglima Garang would have an impact on the increase in climate change problems in Malaysia.

Esa (2010) reported that half of the respondents of preservice teachers have moderate knowledge but excellent environmental practices compared to the knowledgeable teachers. Preservice biology teachers demonstrate a good knowledge about concepts and facts of the environment that will assist them in integrating environmental education into their teaching. Similarly, Ahmad and Saidin (2016) noted that geography teachers have a high knowledge of the environment regardless of the location of their workplace whether in the city or rural areas.

According to McNeal et al (2017); Seroussi et al (2019), the role of teachers as well as the knowledge and awareness of teachers (Stevenson et al., 2016) are necessary to convey knowledge to students and the community about climate change. It is a worldwide concern to know that teachers in secondary and primary schools have low levels of awareness of climate change. They also have less motivation in this matter by giving the perception that there is no need for them to know about climate change based on studies by Dawson (2012), Liu et al (2015); McNeal et al (2017); Plutzer and Hannah (2018); Seow and Ho (2016) on inservice teachers as well as preservice teachers. Although most studies have been conducted on in-service teachers as well as preservice teachers, Seroussi et al (2019) and Plutzer and 
Hannah (2018) pointed out that there are still teachers who avoid teaching topics related to climate change and thus do not contribute to environmental education to students.

Hestness et al (2017) identified that there was a mistake in the understanding and belief of preservice teachers where they believed that humans are not responsible for climate change. According to Plutzer and Hannah (2018), 13-16\% of teachers in the United States still think that climate change is caused by natural causes and some even said that they are not sure why climate change can happen. According to McNeal et al. (2017), although preservice teachers' understanding of the causes and consequences of climate change is increasing, only a small number take the initiative and think that each of their eco-friendly actions can help reduce the effects of climate change.

Meanwhile, Higde et al. (2017) discovered that disinterest in and scepticism about the reality of climate change resulted in negative behaviour towards climate change in Turkey. If climate change is considered to pose a risk to their lives, then the awareness and belief will arise. Other than that, having knowledge, awareness, and risk perception of climate change will lead them to seek action initiatives to reduce the impact of climate change. The findings from Higde's (2007) study are supported by Seroussi et al (2019), who found that most teachers in Israel believe that climate change is taking place and they acknowledge human responsibility for the phenomenon. However, they still have many misunderstandings and gaps in the knowledge of the causes and consequences of climate change. They are also not ready to show attitudes and behaviours to reduce the climate change effects.

Studies on climate change have been widely conducted in Malaysia through various perspectives but the number of studies on climate change awareness among students and preservice teachers is scarce. Previous studies involved the in-service teachers and preservice science teachers, but studies on climate change issues among teachers of other subjects are limited. Besides, there are many studies on environmentally friendly behaviour but not on climate change issues. Most research in Malaysia focused on perception and public awareness instead of preservice teachers. Previous studies on climate change involving preservice teachers from abroad have been used as reference for this study. However, studies on environmental issues and climate change in Malaysia involving students, in-service teachers, and the public are also benchmarked for the level of awareness, knowledge, risk perception, attitudes, and climate change-friendly behaviours of preservice teachers in Malaysia.

Syaiffudin and Hashim (2019) found that there is a relationship between the levels of awareness among the population to control the problem of climate change. However, the relationship is quite weak and this study also discovered that the level of unsatisfactory awareness among the residents of Telok Panglima Garang would have an impact on the increase in climate change problems in Malaysia.

Esa (2010) reported that half of the respondents of preservice teachers have moderate knowledge but excellent environmental practices compared to the knowledgeable teachers. Preservice biology teachers demonstrate a good knowledge about concepts and facts of the environment that will assist them in integrating environmental education into their teaching. Similarly, Ahmad and Saidin (2016) noted that geography teachers have a high knowledge of the environment regardless of the location of their workplace whether in the city or rural areas.

According to McNeal et al (2017); Seroussi et al (2019), the role of teachers as well as the knowledge and awareness of teachers (Stevenson et al., 2016) are necessary to convey knowledge to students and the community about climate change. It is a worldwide concern to know that teachers in secondary and primary schools have low levels of awareness of 
climate change. They also have less motivation in this matter by giving the perception that there is no need for them to know about climate change based on studies by Dawson (2012); Liu et al (2015); McNeal et al (2017); Plutzer and Hannah (2018); and Seow and Ho (2016) on in-service teachers as well as preservice teachers. Although most studies have been conducted on in-service teachers as well as preservice teachers, Seroussi et al. (2019) and Plutzer and Hannah (2018) pointed out that there are still teachers who avoid teaching topics related to climate change and thus do not contribute to environmental education to students.

Hestness et al. (2017) identified that there was a mistake in the understanding and belief of preservice teachers where they believed that humans are not responsible for climate change. According to Plutzer and Hannah (2018), 13-16\% of teachers in the United States still think that climate change is caused by natural causes and some even said that they are not sure why climate change can happen. According to McNeal et al (2017), although preservice teachers' understanding of the causes and consequences of climate change is increasing, only a small number take the initiative and think that each of their eco-friendly actions can help reduce the effects of climate change.

Meanwhile, Higde et al (2017) discovered that disinterest in and scepticism about the reality of climate change resulted in negative behaviour towards climate change in Turkey. If climate change is considered to pose a risk to their lives, then the awareness and belief will arise. Other than that, having knowledge, awareness, and risk perception of climate change will lead them to seek action initiatives to reduce the impact of climate change. The findings from Higde's (2007) study are supported by Seroussi et al. (2019), who found that most teachers in Israel believe that climate change is taking place and they acknowledge human responsibility for the phenomenon. However, they still have many misunderstandings and gaps in the knowledge of the causes and consequences of climate change. They are also not ready to show attitudes and behaviours to reduce the climate change effects.

\section{Conceptual Framework}

The model that has been proposed by Masud et al (2013) is a foundation for this study. This is because the proposed model is unique in examining the awareness, knowledge, and risk perception of climate change, and has a positive impact on attitudes and mediation effects on pro-environmental behaviour towards climate change. Based on the model for understanding the awareness, knowledge, and perception of climate change in Malaysia (Masud et al., 2013) and the model of predictors of environmental behaviour (PEB) (Hines et al., 1987), there is a significant influence on the climate change-friendly behaviour of preservice teachers. Figure 1 shows a new model suggested by the researchers to examine the relationships between the level of awareness, knowledge, risk perception, and attitude towards climate change which have a significant effect on the climate change-friendly behaviour of preservice teachers. 


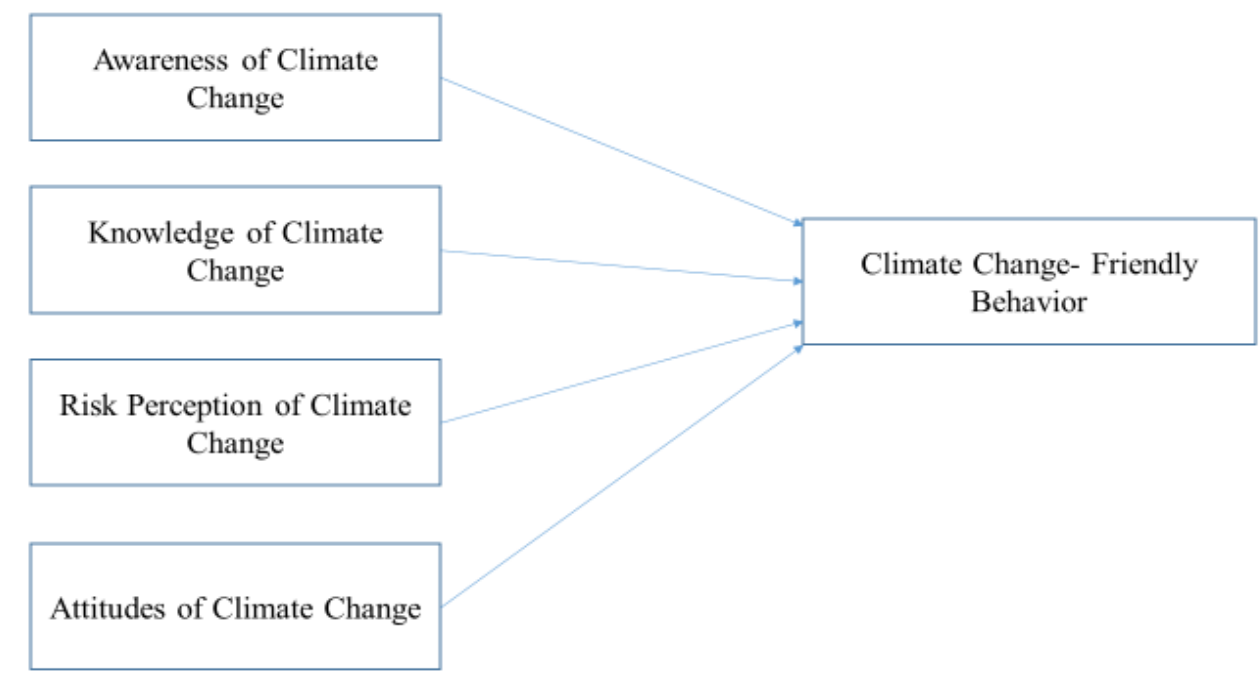

Figure 1. Model of climate change-friendly behaviour for preservice teachers.

The selection of preservice teachers in this study is to increase the awareness of environmental issues and climate change so that they are aware of this issue and can provide a positive response to this issue. Preservice teachers are important in the future world of education to disseminate information about climate change. The purpose of this study is to examine the level of awareness, knowledge, risk perception, and attitude towards climate change, which have a significant relationship with the climate change-friendly behaviour of preservice teachers. The results of this study are expected to assist the researchers, educators, and policymakers in predicting educational implications.

\section{Methodology}

\section{Research Design}

This study is a quantitative research which employed survey questionnaires. A set of questionnaires was used for data collection purposes. According to Idris (2013), using questionnaires is a very popular survey method in social science research which can be used to discover attitudes, beliefs, values, and behaviours, have specific scientific characteristics, and can include a large population through a small sample. The primary data to identify the level of awareness, knowledge, risk perception, and preservice teachers' friendly attitude and behaviour towards climate change are through questionnaires, while the secondary data are through books and articles obtained from online sources.

\section{Location, Population, and Study Sample}

This study was conducted in four public universities in Selangor, namely Universiti Kebangsaan Malaysia (UKM), Universiti Putra Malaysia (UPM), International Islamic University Malaysia (IIUM), and Universiti Teknologi MARA (UITM). The rationale for selecting the study location is based on several factors such as there are differences in the fields of study offered in each faculty of education at the universities. In addition, the universities are located in the state of Selangor. It is common knowledge that Selangor contributes to the rapid development of the country as it is largely considered as Malaysia's industrial hub and 
also the place of development of the world of education (Department of Statistics Malaysia, 2020). The study population is undergraduate students in various education fields who are known as preservice teachers at UKM, UPM, IIUM, and UiTM. A total of 256 preservice teachers representing the population of preservice teachers in various fields were randomly selected as the sample for this study. The sample size was determined by referring to the sample size determinants of Krejcie and Morgan (1970).

\section{Research Instrument}

This study employed a set of survey questions adapted from previous studies and quoted in the study of Masud et al. (2013), who studied about pro-environmental behavioural prediction models and public knowledge of climate change. The researchers constructed a questionnaire based on previous studies as applied by Masud et al. (2013). The questionnaire was also modified and improved according to suitability in accordance with the requirements of the study. The questionnaire is divided into three parts:

Part A: Demographic information of respondents. Part A consists of university, gender, age, race, religion, year and field of study, current course of study, Sijil Pelajaran Malaysia (SPM), state of birth, and state of residence.

Part B: Items on preservice teachers' awareness, knowledge, and risk perception of climate change.

Part C: Items on preservice teachers' friendly attitudes and behaviours towards climate change.

\section{Pilot Study and Item Reliability}

A pilot study was conducted before the actual study. According to Osman et al. (2007), the purpose of the pilot study is to measure the validity and reliability of the items contained in the questionnaire before the research instrument is administered to the actual respondents. This is supported by Fraenkel and Wallen (2009) who stated that the purpose of the pilot study is to test and improve validity and reliability. In this study, a pilot study was conducted at the University of Malaya consisting of preservice teachers in various fields of study and the respondents selected were not actual respondents. A total of 40 respondents were randomly selected to participate in the pilot study. SPSS software version 23.0 was used to test the internal consistency of the instrument. The pilot study found that the item reliability value is $\alpha=0.893$. According to Sekaran (1992), Cronbach's alpha reliability value of less than 0.60 is considered low and unacceptable, a value between $0.60-0.80$ is acceptable, while a value above 0.80 is considered good and has a high reliability.

\section{Study Implementation Procedures}

The research data were obtained by the researchers through online as all the universities were instructed to conduct learning and teaching online due to the COVID-19 pandemic across the country. In this study, the researchers distributed questionnaires to preservice teachers at UKM, UPM, IIUM, and UiTM to find out the level of awareness, knowledge, risk perception, attitude, and friendly behaviour of preservice teachers towards climate change through online applications such as WhatsApp, Telegram, Twitter, and email. 


\section{Result and Discussion}

Descriptive analysis was conducted to analyse the findings of the study in order to know the level of awareness, knowledge, risk perception, and attitude of preservice teachers towards climate change as shown in Table 1.

Table 1

Descriptive Analysis of the Level of Awareness, Knowledge, Risk Perception, and Attitude of Preservice Teachers towards Climate Change

\begin{tabular}{|c|c|c|c|}
\hline Construct & SD & $\begin{array}{l}\text { Mean } \\
\text { score }\end{array}$ & Level \\
\hline Awareness & 0.513 & 4.53 & Very high \\
\hline Knowledge & 0.513 & 4.42 & Very high \\
\hline Risk perception & 0.533 & 4.34 & Very high \\
\hline Attitudes & 0.550 & 3.96 & High \\
\hline
\end{tabular}

Relationship between Awareness, Knowledge, Risk Perception, Attitude, and Friendly Behaviour of Preservice Teachers towards Climate Change

This study employed a parametric analysis to analyse the relationship between normally distributed data, then the results obtained will provide the conclusions to indicate the relationships between the variables tested. The results of correlation test analysis to show the relationships between the level of awareness, knowledge, risk perception, and attitude of preservice teachers' towards climate change are in Table 2.

Table 2

The Relationship between the Level of Awareness, Knowledge, Risk Perception, and Attitude of Preservice Teachers towards Climate Change

$\begin{array}{ccccc}\text { Construct } & \text { Pearson } & \text { Correlation of } & \text { Significant level } & \text { Interpretation } \\ \text { correlation } & \text { determination } & \text { of relionship } \\ \text { coefficient } & \left(r^{2}\right) & \text { strength }\end{array}$

( $r)$

\begin{tabular}{lllll}
\hline $\begin{array}{l}\text { Awareness towards } \\
\text { climate change- } \\
\text { friendly behaviour }\end{array}$ & 0.472 & 0.2227 & $>0.0001^{* *}$ & Moderate \\
\hline $\begin{array}{l}\text { Knowledge towards } \\
\text { climate change- }\end{array}$ & 0.402 & 0.1616 & $>0.0001^{* *}$ & Weak \\
friendly behaviour & & 0.1936 & $>0.0001^{* *}$ & Moderate \\
\hline $\begin{array}{l}\text { Risk perception } \\
\text { towards climate } \\
\text { change-friendly } \\
\text { behaviour }\end{array}$ & 0.440 & & & \\
\hline $\begin{array}{l}\text { Attitudes towards } \\
\text { climate change- } \\
\text { friendly behaviour }\end{array}$ & 0.375 & 0.1406 & $>0.0001^{* *}$ & Weak \\
\hline
\end{tabular}

** Significant at level 0.05

Level of awareness, knowledge, risk perception, and attitude were found to have a significant relationship with the climate change-friendly behaviour of preservice teachers in 
Selangor. Although the strength of the relationship between awareness and risk perception with friendly behaviour is at a moderate level, it can be explained that there is a relationship that causes a person's friendly behaviour to be influenced by high level of awareness and risk perception. Moreover, there is a weak but positive relationship between the level of knowledge and attitude towards friendly behaviour. This indicates that knowledge and attitudes also influence the friendly behaviour of preservice teachers. The preservice teachers have a high level of knowledge, awareness, risk perception, and attitudes about climate change knowing that climate change has a negative impact on life. However, in reality, they still do not show friendly behaviour towards climate change in their daily life.

The current study was adapted from Masud et al. (2013), but the results differ. Masud et al. (2013) found that there was no significant relationship between risk perception and friendly behaviour towards climate change. The current study found that the preservice teachers agree that climate change has a negative impact on life, but they do not have the willingness to show friendly behaviour towards reducing the effects of climate change.

The relationship between the level of attitude and friendly behaviour of preservice teachers towards climate change is weak. This illustrates that although preservice teachers have a positive attitude towards climate change, the willingness to show friendly behaviour towards reducing the effects of climate change is still weak. This may be due to various external factors that were not covered in this study. This study supports the behavioural theory model by Ajzen (1985) which is to identify that attitude does not directly determine behaviour, but it will indirectly go through the intention to do something.

Furthermore, this study is in line with the findings of Abu Bakar et al. (2013) in which the level of environmental awareness among university students is good for environmentally friendly behaviour. However, the results demonstrate that a high level of awareness in university students does not have a strong impact on their environmentally friendly behaviour.

\section{Conclusion}

Climate change is a serious threat nowadays. Therefore, society including preservice teachers need to have awareness and knowledge on climate change issues. Although preservice teachers are students and prospective teachers, they are among the most important persons in education who need to have a high level of knowledge and awareness about climate change. This is because the preservice teachers will pass on the knowledge that they have to school students. If the preservice teachers do not have the awareness and knowledge of climate change, they might indirectly disseminate knowledge that will lead to misconceptions in students about climate change. This study found that there are significant relationships between the level of awareness, knowledge, risk perception, and attitude with the climate change-friendly behaviour of preservice teachers. However, the relationship between the level of awareness and risk perception of climate change-friendly behaviour is moderate, while the level of knowledge and attitude towards climate change-friendly behaviour of preservice teachers is weak.

This study only focused on samples in four universities, which are UKM, UPM, IIUM, and UiTM. The data were collected from a small number of samples. Therefore, the findings of the study cannot be generalised to other populations. However, to obtain more detailed data on climate change issues, it is recommended to conduct case studies through interviews and studies on the preservice teachers' belief in climate change rather than just identifying the relationship between the variables in this study. Furthermore, the findings reveal that the 
high level of knowledge and awareness of preservice teachers does not influence them to change their lifestyle towards environmentally friendly behaviour to reduce the effects of climate change. Universities are encouraged to work with private bodies and NGOs in planning various field activities and experiences to inculcate friendly attitudes and behaviours among preservice teachers towards climate change to reduce the impact of climate change from continuing.

Apparently if teachers and educators have high level of awareness, knowledge, risk perception and goods attitude toward climate change, they will portray climate changefriendly behaviour and also educate their students. Currently, teachers and educators offend overlook to emphasize climate change friendly behaviour towards students, therefore this research contribute a big impact for future generation education to develop new generation with high value of climate change-friendly behaviour.

Acknowledgement.

To the research grant number GGPM-2019- 010

\section{References}

Abu Bakar, H., Abd Aziz, N., Mohd Narwawi, N. A., Abd Latif, N., Mohd ljas, N., \& Hamzah Sharaai, A. (2013). Kajian perhubungan antara kesedaran alam sekitar dengan tingkah laku mesra alam sekitar dalam kalangan pelajar universiti; Kajian kes: Pelajar tahun satu Universiti Putra Malaysia (UPM).

Ahmad, A. L., A. Rahim, S., Pawanteh, L., \& Ahmad, F. (2012). The understanding of environmental citizenship among Malaysian youths: A study on perception and participation. Asian Social Science, 8(5), 85-92. https://doi.org/10.5539/ass.v8n5p85

Ahmad @ Shaari, M. Z., \& Saidin, N. (2016). Pengetahuan tentang kearifan tempatan berkait alam sekitar dalam kalangan guru geografi (Local wisdom on environmental knowledge among geography teachers). Geografi, 4(2), 1-8. https://ejournal.upsi.edu.my/index.php/GEOG/article/view/1928

Dawson, V. (2012). Science teachers' perspectives about climate change. Teaching Science, 58(3), 8-13.

Department of Statistics Malaysia. (2020). https://www.dosm.gov.my

Esa, N. (2010). Environmental knowledge, attitude and practices of student teachers. International Research in Geographical and Environmental Education, 19(1), 39-50. https://doi.org/10.1080/10382040903545534

Fraenkel, J. R., \& Wallen, N. E. (2009). How to design and evaluate research in education (7th ed.). McGraw-Hill.

Hestness, E., McGinnis, J. R., Riedinger, K., \& Marbach-Ad, G. (2017). A study of teacher candidates' experiences investigating global climate change within an elementary science methods course. Journal of Science Teacher Education, 22(4), 351-369. https://doi.org/10.1007/s10972-011-9234-3

Higde, E. (2017). Identifying determinants of pro-environmental behaviors: A case for climate change [Unpublished master's thesis]. Middle East Technical University.

Hines, J. M., Hungerford, H. R., \& Tomera, A. N. (1987). Analysis and synthesis of research on responsible pro-environmental behavior: A meta-analysis. The Journal of Environmental Education, 18(2), 1-8. https://doi.org/10.1080/00958964.1987.9943482

Idris, N. (2013). Penyelidikan dalam pendidikan. McGraw-Hill Education (Malaysia) Sdn. Bhd. 
Syaiffudin, I. A. S., \& Md. Hashim, N. (2019). Persepsi umum penduduk Telok Panglima Garang terhadap perubahan iklim di Malaysia (General perceptions of Telok Panglima Garang residents on the climate change in Malaysia). Jurnal Wacana Sarjana, 2(3), 1-14. http://spaj.ukm.my/jws/index.php/jws/article/view/157

Krejcie, R. V., \& Morgan, D. W. (1970). Determining sample size for research activities. Educational Psychological Measurement, 30, 607-610. https://doi.org/10.1177/001316447003000308

Liu, S., Roehrig, G., Bhattacharya, D., \& Varma, K. (2015). In-service teachers' attitudes, knowledge and classroom teaching of global climate change. Science Educator, 24(1), 12-22.

Madawan, P., Yasin, M. R., \& Hamzah, M. I. (2016). Pengetahuan, sikap dan kesediaan pelajar kolej matrikulasi terhadap kemahiran berfikir aras tinggi (KBAT) dalam pembelajaran. Proceedings of the Seminar on Transdiscipline Education.

Masud, M. M., Akhtar, R., Afroz, R., Al-Amin, A. Q., \& Kari, F. B. (2013). Pro-environmental behavior and public understanding of climate change. Mitigation and Adaptation Strategies for Global Change, 20(4), 591-600.

McNeal, P., Petcovic, H., \& Reeves, P. (2017). What is motivating middle-school science teachers to teach climate change? International Journal of Science Education, 39(8), 1069-1080. https://doi.org/10.1080/09500693.2017.1315466

Hashim, M. N. (2015). Kecelaruan iklim global: Satu analisis awal (Global climatic confusion: A preliminary analysis). Geografia: Malaysian Journal of Society and Space, 11(1), 2435.

Nerem, R. S., Beckley, B. D., Fasullo, J. T., Hamlington, B. D., Masters, D., \& Mitchum, G. T. (2018). Climate-change-driven accelerated sea-level rise detected in the altimeter era. Proceedings of the National Academy of Sciences, 115(9), 2022-2025. https://doi.org/10.1073/pnas.1717312115

Osman, K., Haji Iksan, Z., \& Halim, L. (2007). Sikap terhadap sains dan sikap saintifik di kalangan pelajar sains. Jurnal Pendidikan Malaysia, 32, 39-60.

Plutzer, E., \& Hannah, A. L. (2018). Teaching climate change in middle schools and high schools: Investigating STEM education's deficit model. Climatic Change, 149, 305-317. https://doi.org/10.1007/s10584-018-2253-8

Plutzer, E., McCaffrey, M., Hannah, A. L., Rosenau, J., Berbeco, M., \& Reid, A. H. (2016). Climate confusion among US teachers. Science, 351(6274), 664-665. https://doi.org/10.1126/science.aab3907

Poortinga, W., Whitmarsh, L., Steg, L., Böhm, G., \& Fisher, S. (2019). Climate change perceptions and their individual-level determinants: A cross-European analysis. Global Environmental Change, 55, 25-35. https://doi.org/10.1016/j.gloenvcha.2019.01.007

Saad, S., Kamarudin, T. F., \& Awang, A. H. (2018). Pengetahuan dan sokongan belia terhadap dasar kerajaan mengenai perubahan iklim (Youth knowledge and support for government policy towards climate change). Geografia: Malaysian Journal of Society and Space, 14(1), 130-141. https://doi.org/10.17576/geo-2018-1401-10

Sekaran, U. (1992). Research methods for business: A skill-building approach (2nd ed.). John Wiley \& Sons, Inc.

Seow, T., \& Ho, L.-C. (2016). Singapore teachers' beliefs about the purpose of climate change education and student readiness to handle controversy. International Research in Geographical and Environmental Education, 25(4), 358-371. https://doi.org/10.1080/10382046.2016.1207993 
Seroussi, D. E., Rothschild, N., Kurzbaum, E., Yaffe, Y., \& Hemo, T. (2019). Teachers' knowledge, beliefs, and attitudes about climate change. International Education Studies, 12(8), 33-45. https://doi.org/10.5539/ies.v12n8p33

Stevenson, K. T., Peterson, M. N., \& Bradshaw, A. (2016). How climate change beliefs among U.S. teachers do and do not translate to students. PloS One, 11(9), 1-11. https://doi.org/10.1371/journal.pone.0161462

Zakariah, N. D. (2016). Pengetahuan, sikap dan kreativiti guru sains sekolah rendah terhadap pendidikan STEM [Unpublished master's thesis]. Universiti Kebangsaan Malaysia. 